DOI: https://doi.org/10.34069/AI/2021.47.11.24

How to Cite:

Pinkovetskaia, I.S., Schennikova, N.V., Bakanova, M.V., Ozhegova, E.Y., \& Safonova, O.Y. (2021). Gender aspects of entrepreneurial opportunities and abilities. Amazonia Investiga, 10(47), 234-239. https://doi.org/10.34069/AI/2021.47.11.24

\title{
Gender aspects of entrepreneurial opportunities and abilities
}

\section{Гендерные аспекты предпринимательских возможностей и способност}

Received: October 20, 2021

\begin{abstract}
To date, the involvement of the population in the creation of a business has become an urgent problem. Therefore, the purpose of our study was to determine the opinions of adults that have developed in various states about the opportunities and abilities they have to open their own enterprises. The results of a survey of the adult population on this problem were used as empirical data. The survey conducted in 2018 covered 59 states located in different parts of the world. Our study was aimed at assessing the existing gender differences. The computational experiment allowed the development of six mathematical models. The study showed that in most countries men are more optimistic about their opportunities and abilities to participate in entrepreneurial activities.
\end{abstract}

Keywords: entrepreneurship, people's opinions, men, women, creating their own businesses.
Accepted: November 30, 2021

\begin{abstract}
Аннотация
Одной из наиболее актуальных проблем развития современного предпринимательства является привлечение новых людей в создание бизнесов. Поэтому целью нашего исследования являлось определение сложившихся в различных государствах мнений взрослых людей об имеющихся у них возможностях и способностях открытия собственных предприятий. В качестве эмпирических данных использовались итоги опроса взрослого населения по указанной проблеме. Опрос, проведенный в 2018 году, охватывал 59 государств, расположенных в разных частях света. Проведенная нами работа была направлена на оценку имеющихся гендерных различий. Вычислительный эксперимент позволил разработать шесть моделей. Исследование продемонстрировало, что во многих странах мужчины более оптимистически оценивают свои возможности и способности по участию в предпринимательской деятельности.
\end{abstract}

Ключевые слова: предпринимательство, мнения людей, мужчины, женщины, создание собственных бизнесов.

\footnotetext{
${ }^{103}$ Economic Analysis and State Management Department, Ulyanovsk State University, Ulyanovsk, Russia.

${ }^{104}$ Translation and Translation Studies Department, Penza State University, Penza, Russia.

105 Translation and Translation Studies Department, Penza State University, Penza, Russia.

${ }^{106}$ Translation and Translation Studies Department, Penza State University, Penza, Russia.

${ }^{107}$ Translation and Translation Studies Department, Penza State University, Penza, Russia.
} 


\section{Introduction}

Entrepreneurs now play a significant role in the economies of increasing part modern countries. They are the owners of most firms, both in developed and developing countries, they create about half of all jobs and provide competition in the markets for goods and services (Kraemer-Eis et al., 2017; Pinkovetskaia et al., 2020a). Entrepreneurship also plays important social role in society life (Pinkovetskaia et al., 2020b).

To date, the involvement of the population in the creation of a business has become an urgent problem. This process is largely determined by perceived entrepreneurial opportunities and abilities. The issues of their perception by adults people have been considered in several scientific publications. For example, the perceived opportunities are discussed in the articles (Renko et al., 2012; Davidsson, 2015; Linan et al., 2011). The perception of entrepreneurial abilities is discussed in the works (Bayon et al., 2012; Walker et al., 2013; Naser et al., 2018). Given the growing role of gender studies in entrepreneurship (Carlianne et al., 2016), this article examines the existing differences in the perception of entrepreneurial opportunities and abilities of female and male. The need for a deeper study of the problem of gender differences in opinions about entrepreneurial opportunities and abilities has been justified in such scientific publications as (Dabic et al., 2012; Pinkovetskaia et al, 2021a).

The purpose of the study is to assess the level of adults people perception of their entrepreneurial opportunities and abilities in modern national economies. Our study presupposed four phases. First phase - information was formed, interpreting the opinions of women and men about their opportunities and abilities to create their own businesses. Second phase - the relative indicators were assessed on entrepreneurial opportunities and abilities for female and male in the total number of these gender strata of the population. Third phase - the average values of these indicators for the countries were determined as well as the ranges of the values for most of the countries. At the fourth phase, a comparative investigation was carried out, that helped to identify the countries with the minimum and maximum values of the indicators.

The study used the results of surveys conducted in 59 countries during the implementation of the Global Entrepreneurship Monitor as background information (Global Entrepreneurship Monitor, 2019). The surveys of adults people (18-64 years old) in these countries have provided opinions of people on their perceptions of entrepreneurial opportunities and abilities.

Our study undertaken the examination of six relative indicators characterizing assessment of opportunities and abilities to create a new business in 2018:

- $\quad$ the proportion of women who believe that they have opportunities for entrepreneurship, in the number of adult women (indicator 1);

- the proportion of men who believe that they have opportunities for entrepreneurship, in the whole number of adult men (indicator 2);

- the coefficient reflecting the ratio of indicators 1 and 2 (indicator 3);

- the proportion of female who believe that they contain abilities to create a business, in the number of adult women (indicator 4);

- the proportion of men who believe that they have the abilities to create a business, in the total number of adult men (indicator 5);

- the coefficient reflecting the ratio of indicators 4 and 5 (indicator 6).

The study tested the following five hypotheses $(\mathrm{H})$ :

H1 - entrepreneurial opportunities in most countries differ significantly among different gender strata;

H2 - entrepreneurial abilities in most countries differ significantly among different gender strata;

H3 - the presence of significant differences in the values of each of the indicators 1-6 is characteristic for different countries;

H4 - indicators 1-6 do not depend on which parts of the world countries are located in;

H5 - indicators 1-6 do not depend on what incomes of the population have been achieved in their respective countries.

Modeling of empirical information in our study used normal distribution functions. The articles (Pinkovetskaia et al., 2021b; Pinkovetskaia et al., 2019) presents a methodological approach to their 
development and use to determine average values for the countries under consideration, as well as the ranges of values for most of the countries. At the final phase of our work, countries were identified that were characterized by indicators significantly different from the average values of indicators, both up and down.

\section{The results of the computational experiment}

Modeling of empirical information was carried out using the Statistics software package. At the same time, the initial data was grouped and distribution models for 59 countries of each of the six indicators were constructed:

- the proportion of female who believe that they have the opportunity to start a business, in the number of adult women, $\%$

$$
y_{1}\left(x_{1}\right)=\frac{700.63}{16.05 \times \sqrt{2 \pi}} \cdot e^{-\frac{\left(x_{1}-42.86\right)^{2}}{2 \times 16.05 \times 16.05}}
$$

- the proportion of men who believe that they have the opportunity to create a business, in the total number of adult men, $\%$

$$
y_{2}\left(x_{2}\right)=\frac{560.52}{16.07 \times \sqrt{2 \pi}} \cdot e^{-\frac{\left(x_{2}-47.45\right)^{2}}{2 \times 16.07 \times 16.07}}
$$

- the coefficient reflecting the ratio of indicators 1 and 2

$-$

$$
y_{3}\left(x_{3}\right)=\frac{5.16}{0.10 \times \sqrt{2 \pi}} \cdot e^{-\frac{\left(x_{3}-0.89\right)^{2}}{2 \times 0.10 \times 0.10}}
$$

- $\quad$ the proportion of women who believe that they have the abilities to create a business, in the number of adult women, $\%$

$$
y_{4}\left(x_{4}\right)=\frac{674.29}{14.02 \times \sqrt{2 \pi}} \cdot e^{-\frac{\left(x_{4}-43.91\right)^{2}}{2 \times 14.02 \times 14.02}}
$$

- $\quad$ the proportion of men who believe that they have the abilities to create a business, in the total number of adult men, $\%$

$$
y_{5}\left(x_{5}\right)=\frac{590.12}{13.10 \times \sqrt{2 \pi}} \cdot e^{\frac{-\left(x_{5}-55.28\right)^{2}}{2 \times 13.10 \times 13.10}}
$$

- $\quad$ the coefficient reflecting the ratio of indicators 4 and 5

$$
-
$$

$$
y_{6}\left(x_{6}\right)=\frac{6.64}{0.13 \times \sqrt{2 \pi}} \cdot e^{-\frac{\left(x_{6}-0.77\right)^{2}}{2 \times 0.13 \times 0.13}} .
$$

The examination of particularities describing the prevailing opinions of women and men about their entrepreneurial capabilities and abilities in the economies under consideration. Column 2 (table 1) contains data characterizing the median values of the indicators. 
Table 1.

Characteristic perceived entrepreneurial opportunities and abilities.

\begin{tabular}{|c|c|c|}
\hline Indicator & $\begin{array}{l}\text { Average } \\
\text { values }\end{array}$ & $\begin{array}{l}\text { Values for most of the } \\
\text { countries }\end{array}$ \\
\hline 1 & 2 & 3 \\
\hline $\begin{array}{l}\text { the proportion of women who believe that they have the opportunity to } \\
\text { start a business, in the number of adult women, } \%\end{array}$ & 42.86 & 26.81-58.91 \\
\hline $\begin{array}{l}\text { the proportion of men who believe that they have the opportunity to } \\
\text { create a business, in the total number of adult men, } \%\end{array}$ & 47.45 & $31.38-63.52$ \\
\hline the coefficient reflecting the ratio of indicators 1 and 2 & 0.89 & $0.79-0.99$ \\
\hline $\begin{array}{l}\text { the proportion of women who believe that they have the abilities to } \\
\text { create a business, in the number of adult women, } \%\end{array}$ & 43.91 & $29.89-57.91$ \\
\hline $\begin{array}{l}\text { the proportion of men who believe that they have the abilities to } \\
\text { create a business, in the total number of adult men, } \%\end{array}$ & 55.28 & $42.18-18.38$ \\
\hline the coefficient reflecting the ratio of indicators 4 and 5 & 0.77 & $0.64-0.90$ \\
\hline
\end{tabular}

Source: Calculations were made by the authors based on functions (1)-(6).

\section{Discussion of results}

The average proportion of women who believe they have business opportunities, in the gender strata, accomplished $42.9 \%$. The corresponding indicator for men was $47.45 \%$ (1.1 times higher). The tendency for men to exceed in this indicator is typical for most of the countries. Exceptions were observed in a few countries. In three countries, namely Argentina, Indonesia, and Vietnam, the values of indicator business opportunities for women and men were equal. In five countries, namely Latvia, Kazakhstan, the United Arab Emirates, Taiwan and the Russian Federation, the perceived opportunities for women to start businesses were higher than those of men. The average value of the coefficient reflecting the ratio of indicators 1 and 2 was 0.89 . This allows us to conclude that hypothesis (H1) about what in most countries entrepreneurial opportunities differ significantly among different gender strata.

The data in Table 1 indicate that in average on the countries a small part of the residents see the possibility of entrepreneurial activity as the beginning or continuation of their life career.

The proportion of women who believe they have the abilities to start a business, in the gender strata, accomplished $43.9 \%$. The corresponding indicator for men was 55.3\% (1.2 times higher). The tendency for men to exceed this indicator is typical for most of the countries. Exceptions were observed in a few countries. Six countries, namely Indonesia, Cyprus, Israel, Kazakhstan, Saudi Arabia and Vietnam, had equal rates for women and men. In Angola, the perceived abilities to create businesses for women were higher than those for men. The average coefficient reflecting the ratio of indicators 4 and 5 was 0.77 . This allows us to conclude that hypothesis (H2) about what in most countries entrepreneurial abilities differ significantly among different gender strata.

Both female and male think that the level of their entrepreneurial abilities is slightly higher than the level of entrepreneurial opportunities.

To verify the hypothesis (H3) put forward earlier in the methodological section, the information demonstrated in the third column of the first table was investigated. The analysis showed the presence of significant differences in the values of each of the indicators 1-6, characteristic of different countries. This indicates that $\mathrm{H} 3$ is fulfilled for all six indicators.

At the final phase of our work, countries were identified that were characterized by indicators significantly different from the average values of indicators, both up and down. At the same time, the maximum and minimum values are values that respectively exceed the upper limits of the ranges shown in the third column of Table 1 and the lower limits of the ranges. The results of this analysis are shown in Table 2. Along with the lists of the countries, this table also presents the subdivision of the countries by their geographic location and the level of income of the population. 
Table 2.

Countries with indicators significantly differ from the average values.

\begin{tabular}{|c|c|c|}
\hline Indicator & Maximum & Minimum \\
\hline 1 & 2 & 3 \\
\hline $\begin{array}{l}\text { the proportion of } \\
\text { women who believe } \\
\text { that they have the } \\
\text { opportunity to start a } \\
\text { business, in the } \\
\text { number of adult } \\
\text { women. \% }\end{array}$ & $\begin{array}{l}\text { Canada, Estonia, UAE, Netherlands, } \\
\text { USA, Poland, Sudan, Angola, Saudi } \\
\text { Arabia, Sweden. Four countries are in } \\
\text { Europe, two in North America, two in } \\
\text { Asia, two in Africa. Incomes: big (eight } \\
\text { countries), small (two countries). }\end{array}$ & $\begin{array}{l}\text { Japan, Bosnia and Herzegovina, Greece, } \\
\text { Bulgaria, Iran, Russian Federation, France, } \\
\text { Spain. Six countries are in Europe, two in } \\
\text { Asia. Incomes of the population: High (four } \\
\text { countries), medium (three countries), low } \\
\text { (one country). }\end{array}$ \\
\hline
\end{tabular}

the proportion of men who believe that they have the opportunity to create a business, in the total number of adult men, $\%$

the coefficient reflecting the ratio of indicators 1 and 2

the proportion of women who believe that they have the abilities to create a business, in the number of adult women, \% the proportion of men who believe that they have the abilities to create a business, in the total number of adult men, $\%$

the coefficient reflecting the ratio of indicators 4 and 5
Chile, United Arab Emirates, Canada, Poland, Netherlands, Sudan, USA, Angola, Saudi Arabia, Sweden. Three countries are in Europe, two in Asia, Africa and North America, one in Latin America. Incomes: high (eight countries), low (two countries).

Argentina, Indonesia, Vietnam, Latvia, Kazakhstan, the United Arab Emirates, Taiwan, Russian Federation. Two countries are in Europe, one in Latin America, five in Asia. Incomes: big (two countries), median (three countries), small (two countries).

Guatemala, Colombia, Sudan, Peru, Kazakhstan, Indonesia, Angola, Ecuador, Saudi Arabia. Three countries are in Asia, four in Latin America, two in Africa. Incomes: big (one country), median (five countries), small (three countries).

Chile, Guatemala, Colombia, Angola,

Peru, Ecuador, Lebanon, Sudan, Saudi Arabia. Two countries are in Asia, two in Africa, five in Latin America.

Incomes: big (two countries), median (four countries), small (three countries). Cyprus, Indonesia, Israel, Kazakhstan, Saudi Arabia, Vietnam, Angola. One country is in Europe and Africa, five in Asia. Incomes: big (three countries), median (one country), small (three countries).
Japan, Bosnia and Herzegovina, Bulgaria, Greece, Russian Federation, Iran, Taiwan, Uruguay, Spain. Five countries are in Europe, three in Asia, one in Latin America. Incomes of the population: high (four countries), medium (four countries), low (one country).

France, Bosnia and Herzegovina, Egypt, Japan, Slovak Republic, China, Germany, India. Four of these countries are in Europe, three in Asia, one in Africa. Incomes: big (four countries), median (two countries) and small incomes (two countries).

Japan, China, Russian Federation, Taiwan, Italy, Morocco, Switzerland, Bosnia and Herzegovina, Sweden, France. Five of these countries are in Europe, three in Asia, one in Africa. Incomes: big (six countries), median (two countries), small (one country).

Japan, China, Russian Federation, Taiwan, Morocco, Italy, Israel. Two countries are in Europe, one in Africa, four in Asia. Incomes: big (four countries), median (two countries), small (one country).

Japan, Bosnia and Herzegovina, France, Iran, Italy, Luxembourg, Netherlands, Sweden, Switzerland. Seven countries are in Europe, two in Asia. Incomes: big (eight countries), small (one country).

Source: Developed by the authors based on data from Table 1 and the Global Entrepreneurship Monitor project.

Table 2 provides information on the geographic location of countries with maximum (column 2) and minimum (column 3) values for each of the six indicators assessed in our study. Investigation of data showed in table 2 that indicators 1-6 do not depend on which parts of the world countries are located in. Moreover, indicators 1-6 do not depend on what incomes of the population have been achieved in their respective countries. Thus, hypotheses 4 and 5 were confirmed.

\section{Conclusion}

The purpose of the study to assess people's opinions about the available entrepreneurial opportunities and abilities in the national economies, based on 2018 data, was achieved. The following conclusions have scientific novelty and originality: 
1. The study provided the assessment of the indicators describing the perception of women and men of opportunities and abilities to create businesses.

2. Distribution of theses six indicators on 59 countries was carried out.

3. The study proved that in most of the countries the proportion of women with entrepreneurial opportunities and abilities is lower compared to similar indicators for men.

4. In 2018, there were significant differences in the values of the six indicators under consideration in the countries.

5. The countries with the maximum and minimum values of these six indicators were identified.

The results of our work have a certain theoretical and practical value for public administration and society. The methodological approach to assessing gender differences in the perception of entrepreneurship presented in the article can be applied in further research.

There were limitations on empirical data during the study, since indicators on 59 countries were analyzed.

\section{Bibliographic references}

Bayon, M., Vaillant, Y., \& Lafuente, E. (2012). Antecedents of perceived entrepreneurial ability in Catalonia: the individual and the entrepreneurial context. Journal of Global Entrepreneurship Research, 5(3). https://doi.org/10.1186/s40497-015-0020-0

Carlianne, P., Stephens, H., \& Weinstein, A. (2016). Where are all the self-employed women? Push and pull factors influencing female labor market decisions. Small Business Economics, 46(3), 365-390. https://doi.org/10.1007/s11187-015-9697-2

Dabic, M., Daim, T., Bayraktaroglu, E., Novak, I., \& Basic, M. (2012). Exploring gender differences in attitudes of university students towards entrepreneurship. International Journal of Gender and Entrepreneurship, 4(3), 316-336.

Davidsson, P. (2015). Entrepreneurial opportunities and the entrepreneurship nexus: A reconceptualization. Journal of Business Venturing, 30(5), 674-695.

Global Entrepreneurship Monitor (2019). GEM 2018/2019. Women's Entrepreneurship Report. Global Entrepreneurship Research Association (GERA). London Business School, London, United Kingdom.

Kraemer-Eis, H., Lang, F., Torfs, W., \& Gvetadze, S. (2017). European Small Business Finance Outlook. June 2017. EIF Working Paper 2017/43. http://www.eif.org/news_centre/research/index.htm

Linan, F., Santos, F., \& Fernández, J. (2011). The influence of perceptions on potential entrepreneurs. International Entrepreneurship and Management Journal, 7, 373-390.

Naser, M., Afzal, I., Siddiqui, S., Dutta, S. (2018). Determinants of entrepreneurial capability (EC) environment in ASEAN-05 economies - a log-linear stochastic frontier analysis. Journal of Global Entrepreneurship Research, 8(14). https://doi.org/10.1186/s40497-018-0101-y

Pinkovetskaia, I., Arbeláez Campillo, D., Rojas Bahamón, M., Gromova, T. y Nikitina, I. (2019). Desarrollo del espíritu empresarial femenino en la Federación de Rusia. Amazonia Investiga, 8(18), 111-118. Obtenido de https://amazoniainvestiga.info/index.php/amazonia/article/view/287

Pinkovetskaia, I.S., Aleksandrova, N.R., \& Mingazova, O.N. (2020a). Entrepreneurship in national economics: significance and potential of development. Amazonia Investiga, 9(27), 428-435. https://doi.org/10.34069/AI/2020.27.03.47

Pinkovetskaia, I.S., Arbelaez-Campillo, D.F., Rojas-Bahamon, M.J., Novikov, S.V., Iniesta, D.S.V. (2020b). Social values of entrepreneurship in modern countries. Amazonia Investiga, 9(28), 6-13. https://doi.org/10.34069/AI/2020.28.04.1

Pinkovetskaia, I.S., Berezina, N.V., Navasardyan, A.A., Neif, N.M. (2021a). Gender aspects of entrepreneurs' motivation in modern countries. Amazonia Investiga, 10(39), 218-224. https://doi.org/10.34069/AI/2021.39.03.21

Pinkovetskaia, I., Nuretdinova, Y., Nuretdinov, I., Lipatova, N. (2021b). Mathematical modeling on the base of functions density of normal distribution. Revista de la Universidad del Zulia, 12(33), 34-49. https://doi.org/10.46925//rdluz.33.04

Renko, M., Shrader, R., Simon, M. (2012). Perception of Entrepreneurial Opportunity: A General Framework. Management Decision, 50(7), 1233-1251.

Walker, J.K., Jeger, M., Kopecki, D. (2013). The role of perceived abilities, subjective norm, and intentions. Journal of Entrepreneurship, 22(2), 181-202. 